\title{
The Changing Soaps and Telenovela Genre: Turkish Series Impact Lejla Panjeta*
}

\begin{abstract}
The focus of this work is to establish the inherent features of the genre of series and discuss their importance and impact on society, politics and everyday life. We usually tend to address everything related to TV and sequel featured as series and soaps. This common presumption is wrong on so many levels, because the genre of sequels has many subgenres and mixed genres and they are constantly changing in the light of the new technologies of filmmaking, TV broadcast and demands of the market. The societies in transition are subjected to various media contents among which the greatest popularity is bestowed to the melodramatic narrative of telenovelas. The promotion of cultures and deconstruction of cultural stereotypes inherent to the mass audience is one of the values of this media content. How much does the genre of telenovelas differ in the context of cultural nuances and what is the genesis of the human urgency in retelling the melodramatic and tragic narratives? Is this genre based on Turkish production now trespassing into the territory of ancient tragedy, thus returning to the roots of all the fiction? Is so, why is that happening to this genre? Enormous popularity deriving from these stories is reflected in the prime time broadcasting by Croatians, Serbian and Bosnian TV stations since 2010. The paper will explain the ontogenesis of the popularity, reflections and influences on societies and cultures, and features of this hybrid and changing genre of telenovelas produced in Turkey.
\end{abstract}

Keywords: Serials; Telenovelas; Genre; Propaganda.

\footnotetext{
* Lejla Panjeta, Associate Professor, Faculty of Arts and Social Sciences, International University of Sarajevo; e-mail: lpanjeta@ius.edu.ba 


\section{Introduction}

There is a common joke in Bosnia nowadays, made under the impression of the impact that Turkish series made in the last couple of years: it is said that when the ottomans retreated in 19 century from Bosnia, they claimed: "We'll come back. In the series!" Enormous popularity of these series can be witnessed if nothing else, just by looking at the TV program. There isn't one public, state or private TV in Bosnia-Herzegovina, Croatia, and Serbia that has not at least one Turkish series in the daily schedule. The importance of debating this phenomenon rises from these facts.

Even in the prehistory of feature movies as artistic expression, but also as an entertainment industry, the extraordinary impact that film has on its users was registered. At the same time the effects that film makes, through its immanent persuasive characteristics and identification of audience with film reality, on the opinions, emotions attitudes and behavior of viewers were evident. Becoming aware that there is a possibility to manipulate with these effects the censorship boards that control the content shown in the film are created even at the very early stage of film development. Even in 1917, the Government of the United States has formed the Creel Committee, the authority that was entrusted to make the influence upon the public opinion on the American engagement in the First World War. One of the important media, through which the Government infiltrated its messages, was feature movies. The first showing of the first 
feature movie in the history confirms that the film propaganda and, in general, the impact of film contents on the audience, are of big importance. With the approaching train and in close up to a static camera in the Lumiere brothers' film L'arrivée d'un train en gare de La Ciotat (1895), the viewers screamed and jumped out of the seats. Truthfulness and verisimilitude are the immanent features of narrative in film language. Often the film is now used for propaganda purposes. With the advent of television soap operas that combines cinematic narration and literal rules of dramatic tensions to what the media industry for mass audience serves has greater impact to the society and the individuals. Relaying on this powerful influence and manipulation related film feature, the narrative structure of TV series can be a useful tool for social, cultural and political impacts.

\section{Profitable Industry and Global Popularity}

The popularity of sequels and logies (duology, trilogy, quadrilogy... overwhelming us from bookshops, tobacco shops, and commercials) today is at its peak not only in cinema and TV, but in literature as well. The very first sequels can be found in the ancient storytelling. One of the first stories told in the serial manner is in One thousand and one nights or Arabian nights in which Scheherazade tells a story open ending it each night so she might live another day for her captor needs to hear how it's to be continued. Many classic authors such as Dostojevski, Tolstoy, or Flaubert published installments of their works in the journals such

\footnotetext{
Epiphany: Journal of Transdisciplinary Studies, Vol. 7. No. 1, (2014) (c) Faculty of Arts and Social Sciences
} 
as Ruski Vesnik or Pickwick Club. The first known e-book has emerged from the experiment with the new technologies in an epistolary form of a novel. It was created by Stephen King. Nowadays bestsellers varying from supernatural, to children's books, even pornographic (labeled as erotic) is done at least in three sequels. Recycling ideas and the profit making are the major incentives for authors and publishers or production companies to continue working on the same stuff and make a sequel out of the perfectly normal compact composition. Anticipated sequels end up the storytelling before drama epiphany is reached and right on the edge of climax and/or falling action. That is way the resolution of the plot is to be anticipated. This technique in modern storytelling was invented in $19^{\text {th }}$ century. Apart from creating the first the paperback Charles Dickens was the first author who made a serial when he deliberately left the character hanging from the cliff in the third chapter of 1860 novel Great Expectations. This novel was printed in sequels in a magazine "All the Year Round." The dramaturgy device called cliffhanger is named after this invention.

One of the first cinema sequels is created by Friz Lang within the German expressionist period. Dr. Mabuze is psychological-gothical horror like drama. Similar to this, character sequels are popular in literature. Poirot, Marple, Sherlock Holmes, Robert Langdon and Harry Potter are characters that have many followers, and these days the supporters form a small internet based armies of fans. In TV, the series are often 
made preempting the rights on the lead actors. They become the superstars whose character lives are usually followed with same ardor as their private lives.

Television series have developed into a profitable industry based on the postulates of film and drama arts but, first of all, on the economic requests and sale that rule in the entertainment industry. As nowadays we have significant improvement in HD film industry, today the television series are more like films and not only regarding the quality of the film narrative but also the manner of directing and film photography. As there is a possibility to work with the equipment which is now chipper and more portable, television series are made with more speed, on many different locations, including the action scenes, with many on locations. All these elements enable almost a film quality of an authors work. An example for this is a brilliant Hilal Saral's directing in the Fatmagül'ün suçu ne? series. "Several years back, 'I bought a one-hour (one hour of copyright) Turkish drama for $\$ 600$ or $\$ 700$. Today, there are parties who are willing to pay $\$ 40,000$ for one-hour,' said Adeeb Khair, general manager and owner of Sama Art Productions, a Syrian TV production company which dubs Turkish dramas into colloquial Syrian Arabic. (Al Tamimi, 2012)

The enormous profits of the series witness their popularity or the rating in Turkey as well as in the countries where this cultural product is launched. But as in any other profit industry, it is necessary to have a top-quality product for export. For example 
The soap opera about Suleiman is the most expensive television program in Turkish history. Roughly $\$ 500,000$ is spent per episode, twice the amount of other serials. The show's launch party was held in Cannes, France. Its elaborate, 15-room re-creation of Istanbul's Topkapi Palace has real marble floors, handcrafted woodwork and a mock European throne room. Actors wear exquisite silk and velvet gowns crafted by a leading Turkish costume designer. And the series is directed by Durul and Yağmur Taylan, two siblings known as the Coen Brothers of Turkey (Rohde, 2012).

According to data on one of the Forum.hr dedicated to the Turkish series in the Balkans, in 2011 and 2012 the total financial transactions for 39 Turkish series was 655 million TL (279,5 million Euros). Four of them were produced by Kerem Çatay from Ay Yapim production company Jasmina, 2012). In the countries of the former Yugoslavia (Bosnia-Herzegovina, Croatia, Serbia), which for the cultural and language similarities have an unique cable TV media, the fight for the prime time airing of Turkish series lasts already a year now. In Croatia, the Turkish series

have over flown ... the channels of the two private TV stations with national concessions. In its program from 7 to 15 hours, which ranges 15 hours, Nova TV airs or re-airs six hours of Turkish soap operas: four hours of Fatmagül'ün suçu ne? and two hours of Hanımın Çiftliği. At that same time period the RTL airs or re-airs seven hours of Turkish soap operas: four hours of Muhteşem Yüzyil, two hours of Ezel and one hour of Dudaktan Kalbe (Kasapović, 2012).

In Bosnia-Herzegovina the leading private TV station, OBN, airs in prime time Muhteşem Yüzyil, the series with the highest rating in 2012 and 2013. Public and state TV stations have also at least one hour of Turkish series at different hours during work days. There is also an unprecedented interest for the Turkish series with 
highest rating of all times, Kurtlar Vadisi. The argument for this claim is not only the official rating report, but also the public opinion with regards to the series expressed in local media through various surveys, internet forums and public TV discussions. Here are some examples. Before the airing hours for the mentioned series were publicly announced at Hayat TV station a huge number of viewers called, sent messages or through public nets asked questions when the first episode of the series would be aired. Public competition for a look-alike for the Sultan Suleiman and Sultana Hurem, who won the trip to Istanbul, brought about an enormous interest and that was also a big promotion for the new season of the series. At the address of the OBN TV station about 300 registrations arrived and the social networks were actively incorporated into the process of decision making which Bosnians were the most a look-alike Turkish originals (Clipping). All of this media revolution begins with the broadcast of Binbir Gece (One Thousand and One Nights) at Croatian TV Nova in 2010 .

Again there is the same situation of empty streets, low number of phone calls during the airing of the series and opening of language courses, which was registered in 1997 with the appearance of Latino-American telenovelas and with unprecedented ratings in the region. The influence of LatinoAmerican telenovelas in the region of the former Yugoslavia resembled a mass hysteria. Viewers from Serbia sent official letters to the production team of the Marisol series requesting the 
justice to be served for the main character of the series while the Orthodox Church received many donations for the healing of the leading heroine. In Goražde a local production made an amateur telenovela based on true events that happened in that small town. This resulted in many quarrels and legal suits. The ratings for Muñeca Brava telenovela were even higher than those for Dnevnik (The News) with up to that time the highest ratings in the history of RTVSA and RTVBiH programs. The TV station in Priština which aired $O$ Clone series received the bomb attack threats if they continue to air that series, which according to the allegations of terrorists undermines the foundations of Islam. In Sarajevo the visit of the main actress in Esmeralda series was followed by euphoria in the main streets of this city like it was during former Tito visits to the towns in ex-Yugoslavia (Panjeta, et al, 2005).

Only two years after the end of the war in the region TV stations started to broadcast telenovelas in Spanish. Not being used to Spanish language and love plots with characters from middle and low classes the viewers at the beginning were distrustful as they were already used to sweetie rich class plots in American soap operas or American way of life living in sitcoms. This quite new form of plot finds its faithful fans and junkies waiting for many episodes with intriguing 40 minutes daily events somewhere in Latin America. Bosnian citizens with various religious and national convictions who just went out from the war sit together and watch telenovelas. Broadcasting time of these 
telenovelas is the time of collective sedative for these people, the time reserved for trying to forget the horrors of war that they suffered. Repression, control of mind and universalizing of free time are the basic argument in many critics of the soap operas, which act as a global sedative during the time period of great recessions and socio-political crisis. On the other hand, popularity is piece of evidence for the quality of mass-products that are designed for mass public. Along with everyday airing intended to attract viewers, the basic technical element of directing used in telenovelas are the ending of an episode when action culminates (the so-called "cliffhanger drama technique"), and almost documentary manner for showing real life and love problems of an ordinary person, which by using a close ups as a mean of identification diminishes limits between film fiction and reality.

In the 1990-s the Mexican telenovelas ruled in the Arab world. But in 2008, MBC started to broadcast dubbed Turkish series. According to Al Tamimi (2012)

\begin{abstract}
the last two episodes of Gümüş, shown on August 30, 2008, attracted 85 million viewers in the Middle East and North Africa region, out of which 50 million were females... On a daily basis, the series has been watched by nearly 30 million viewers, he said... Turkish newspaper Hurriyet Daily News was quoted as saying that the soap operas have increased the country's influence abroad, especially in the Balkans and the Middle East, furthering the so-called soft power of Turkish diplomacy. According to Hurriyet, more than 100 Turkish television series have been watched in more than 20 countries this year, earning more than $\$ 60$ million.
\end{abstract}

Globalization and regionalization have found their mutual language through the mass profitable industry of TV series. While 145

Epiphany: Journal of Transdisciplinary Studies, Vol. 7. No. 1, (2014) @ Faculty of Arts and Social Sciences 
one stream tries to unify and universalize, the other one uses the oldest manner and through narrative techniques presents the uniqueness of human fate in given circumstances found in special social systems. Showing in a different manner one culture, about which the other one has earlier developed stereotypic connotations, and breaking so stereotypes, telenovelas and series can be a form of fight against cultural stereotypes control. Therefore, spreading the understanding between cultures, television series and their social networks, through interactions on forums and blog pages become a culture for itself. „The term cult TV would seem to refer to the method of watching and reacting to certain shows rather than referring to the shows themselves" (Fiddy, 2010, p. 230). This series cult is not reserved only for the fans and promotion campaigns of television advertisement agencies. The influence of fiction on reality has spread so much that the series become a subject of parliaments discussions or they cause open conflicts, while in real life the narrative series models are copied so that an individual or a group identify themselves with the fictional characters.

Soap operas are wildly popular in Turkey and are among the country's most vital exports, both in terms of profit and public relations. Before the Mavi Marmara tried to deliver aid to Gaza in May 2010, Turkish soap operas had been illustrating the country's solidarity with Palestinians, often by maligning Israelis. Gümüş, which aired on Kanal D, became a popular soap in the Arab world, and flaunted Turkey's idealized self-image as a nation balancing its Islamic identity with Western behavior like drinking wine and kissing. Soaps have addressed serious issues - the lives of political prisoners, the decline of rural life, the role of women-with typical innuendo and melodrama (Krajeski, 2012). 


\section{Political and Social Impact of the Turkish Serials}

Having in mind a specific feature of television verisimilitude and huge number of recipients, in some social circles there is a certain concern over historic, cultural or political inadequacy or incorrectness with regards to events or characters shown in TV series. The very fact that a certain concern exists is the argument proving that television series are a serious social issue and not only a creative narrative or entertainment product. The alcohol use by fictional characters in the series became an issue that waved the cleric circles because in the Islamic world the religious ban on use of alcohol is important. On the other hand, European viewers are shocked with the fact that there are alcohol beverages in Turkey and even more by the manner in which they are consumed, which is identical with the European one. Therefore

people raised many questions why in that television series the Islamic culture is not presented more intensively. Really, a drama about attitude of a person who lives an honest and moral life, who preys God five times a day, fasts give sadaka and zekiat, goes to pilgrimage to Mecca would be a very boring one as there are no intrigues, cheating or gambling. In so sober and highly raised consciousness condition a person cannot make any big problem. That would be completely uninteresting', adds as a joke Ms. Šiljak-Jesenković... 'When the Ottomans withdrawn from the Balkans they said: We'll be back in TV series' (Dervišević, 2012).

In this interesting comment, interwoven with specific Balkan humor, it is true that there is no drama if there is no conflict, or if there are no tensions caused by strives of characters. It is true that no one wants to see happy and normal persons in the series, films 
or literature. This is the law of dramaturgy and the series are based on this. However, it is not true that alcohol is the main incentive of a conflict. Comparing Turkish and Latino-American series, where due to character of Christian culture alcohol is not forbidden or comparing series with classic literature pieces we find that the fact of consuming alcohol is not the starting force that provoke tragic fate of characters. We do not see alcohol as the drama plot accelerator or motivator in Shakespeare, Dostoevsky, Tolstoy, or Greek tragedies. This tells us that people are the same everywhere and their problems that can inspire the drama for an interesting piece of fiction are deriving from people. This is just the point where the global successfulness of Turkish series lies because only cultural set design backdrop is different from the one to which Europe and the Balkans are used to. However, in Islamic and Arab world there are many complaints regarding the manner in which Islamic culture is portrayed.

After the 2011 premiere of Muhteşem Yüzyil on Turkish TV "critics hurled eggs at billboards advertising the program, protested outside the production company's office and filed more than 70,000 complaints with the Turkish government television agency. The show's producers shortened kissing scenes and toned down certain elements" (Rhode, 2012). Just like Muhteşem Yüzyili, Gümüş, translated as Noor in Arabic, one of the first widely popular series in the Middle East, also deals with some predicaments that are not always in accordance with the Islamic culture and religion.

\footnotetext{
Epiphany: Journal of Transdisciplinary Studies, Vol. 7. No. 1, (2014) ๑ Faculty of Arts and Social Sciences
} 
Some Muslim characters drank wine with dinner and engaged in premarital sex. In one case, a character had an abortion. The lead male character, Muhannad, was the show's handsome hero. A loving, attentive and loyal husband, he supported his wife's career as a fashion designer and treated her as an equal. Their successful marriage -which combined traditional loyalty and modern independence -- was both popular among women and groundbreaking. Some Arabic-language newspapers reported that arguments and even divorces occurred in several countries as a result... Dubbed into colloquial Arabic, censored of its raciest scenes and renamed Noor, the series was a phenomenal hit. Unlike Western soap operas, it focused on an extended family, a strong tradition in Turkey and the region. In 2008, the show's final episode drew an estimated 85 million viewers over the age of 15 , according to $\mathrm{MBC}$, including 50 million women, a figure that represents more than half the adult women in the Arab world (ibid).

Fatwa was issued in Saudi Arabia forbidding Gümüşs and the series was labeled as a secular Turkish assault on Saudi society. According the above mentioned Reuters article, leader of a Saudi religious council said the owner of MBC should be tried and potentially executed for airing broadcasting this series. Nevertheless, the article concludes that

beyond breaking cultural taboos, the shows display something else: Turkey's rapid economic growth... In its soap operas, Turkey is modern, Muslim and prosperous at the same time. Intentionally or not, though, the makers of Turkey's soap operas are creating new roles, new heroes and new cultural norms in a rapidly changing region (ibid.).

According the writings of Emirates.new.com, divorce rates in UAE is increased in percentage of family disputes, for which some experts blame addiction to television programs. In 
accordance with the number of complaints, it is clear that most women who watched these serials neglected their families.

The greater impact of the Turkish series with tragic consequences, then the mentioned cultural and religious disputes, is evident in the killings of five people in Yemen, inspired by the Turkish series Kurtlar Vadisi. Yemeni man has been executed after murdering four men and a woman in an effort to imitate a Turkish soap opera. According to Israel national news

\begin{abstract}
Mohamed al-Ali al-Azab, 31, confessed to his crime prior to his execution, saying he was inspired by the popular Turkish television series Kurtlar Vadisi...The incident began with a dispute between al-Azab and an unidentified man in Yemen's Dawran and resulted in the killing of five people, including the unidentified man's mother (Hirshfeld, 2012).
\end{abstract}

The political issues and political background of the cultural influences are not immune to the effects of Turkish series. The leader of Greece's far-right Golden Dawn party openly invites citizens to boycott Turkish series. "Michaloliakos said it was a shame that Turkish shows were being aired in Greece, which had a unique cultural heritage and said friendly relations between Turks and Greeks was against the well-being of Greece and its citizens" (Kirbak, 2012). Kurtlar Vadisi caused one more political dispute between Israel and Turkey. The series depicts Mossad agents in a negative context. Escalation of the diplomatic crisis between Jerusalem and Ankara was evident after the broadcasting of the scene in which Palestinian women were being raped in Israeli prisons. Apart from the complaints from the 
prisoners, "the Foreign Ministry summoned the Turkish ambassador to Israel for a reprimand in which he was publicly humiliated by being seated at a lower chair than Deputy Minister Daniel Ayalon" (Nahmias, 2012).

In Serbia at the end of March 2012, members of the ultra right campaign Naši (Ours) put up posters all over Belgrade protesting against broadcasting of Muhteşem Yüzyil series, that stated

The Serb history is dramatically falsified. Belgrade did not spread its arms waiting the Sultan to come. On the contrary, all 900 defenders were killed while defending it, and he was not a romantic knight but a brutal conquer... For example, 60 'unbelievers' impaled heads were waiting for him in front of Šabac fortress! (Ilić, 2012).

The Serb historians assert in public media that the history is forged. There is a similar situation in talk shows and media discussions in Bosnia and Herzegovina where the scholars and historians are gathered to discuss incorrectness presented about the life in harem and at the Ottoman palace where they defend the historic figure of this series character. "Master of arts in history and expert collaborator at the History Institute in Sarajevo ... stated that "the series gives a distorted picture of events'، (Dežulović, 2012, p. 11) and he also said that the top politicians in Turkey were not calm about the series fiction (ibid.). Turkish Prime Minister, Erdogan, condemned publically the production team of Muhteşem Yüzyil show. According the Todayszaman.com Turkish Prime minister emphasized „his government issued 
warnings to the series and he hopes that the judicial mechanism will rule appropriately regarding the series. He said there must be a response within the law to those who mock the values of the people" (Anonymous, 2012, November 25).

There are many more examples where fiction contents are interpolated into the everyday lives of people and they are with political and sociological consequences. However, the majority negates the influences that series produce. Describing the plans for developing a TV entertainment network the Hamas leader's teenage son arrived, "complaining about Western music and his sister's taste for the Turkish soap operas. Then the son's cell phone rang. The ring tone was the theme song from Noor" (Kimmelan, 2010).

Under no circumstances the propaganda influences that series produce should not be neglected. However, the above mentioned discussions and opinions seem rather funny, because the polemicists prove a historic correctness making references to an entertaining and artistic creation. However, it is possible that the power the series do have, which is known from the very beginning of the film history, has been transferred from the hands that control political power to the hands that control economy, meaning the hands of those who control profit and budget of productions. Narrative feature of series and the realism in picturing the life itself, make Turkish series a suitable media for discussions about truthfulness in showing. However, "narration 
promises a form of understanding which is not absolute or relative but is somewhere in between" (Kearney, 2009, p. 149). Confusion and conflict that series provoke with regard to historic trutfulness or untrutfulness is not founded. Here we have a fictitious creation which according to an author's vision represents its own narrative (phantasmagoric) world. This is best explained in the statement of the actor who portrays Sultan Suleiman the Magnificent, Halit Ergenç: "There is no political message or any other cultural message...This is a TV series. It is a soap opera" (Rohde, 2012).

Besides already mentioned effects that the fiction of series brings in real life, we cannot neglect many positive effects that television series made. Along with the growth of tourism, a high interest for Turkish language studying (Dervišević, 2012) and the expansion of Turkish economy and its political influence in the Middle East (Rohde, 2012, \& Kimmelman, 2010), the mentioned series broadcasted in Bosnia, Serbia and Croatia are winners of Antalya Television Awards, which is an equivalent to American Emmy, and Turkish actors get the awards for their work even in Vatican, like Murat Yildirim who won a Giusepe Sciacca award. Fatmagül'ün suçu ne? series is used for therapeutic purposes in American clinic for sexually abused women (Canikligil, 2012). According to a post at Hurriyet news portal

Turkish TV series are set to participate in a new campaign from the Urban Planning Ministry to raise earthquake awareness by including scenes that illustrate the dangers of temblors in the country... As part of the campaign, Muhteşem Yüzyll, which follows the intrigues of the harem during the 
reign of Süleyman the Magnificent, will reportedly be asked to include a dramatization of the 1509 earthquake in Istanbul that killed 13,000 people (Anonymous, 2012, July 16).

Popular and profitable television series are a good platform where ideas of public interest can be advertised or social issues raised. Therefore, many campaigns for bringing awareness of different illnesses of a person or society, like stereotypes and prejudice, may appear in television series. As modern narrations follow everyday life of characters, television series are a perfect place where a certain cultural context can be popularized. Namely, there is no a scientific work or a historical fact that can show a certain living cultural and anthropological feature more faithfully than today's television series can. The viewers from a different culture will learn through them, along with a language, much about gastronomy and cultural norms that exist during social gathering like weddings, baby deliveries, deaths and everyday communication and how love and hatred can be expressed in a socially acceptable manner. In countries where the foreign programs are subtitled (Bosnia, Croatia and Serbia are among them) Turkish television series help a lot in the process of language learning and they also offer possibility to notice cultural linguistic differences. For example, the manner in which two persons greet themselves with a form of "good day" in South-Slav languages and culture is rather poor if compared with the one in Turkey. In Turkish culture this kind of greeting can be expressed in many forms as the language is poetic and kindness culturally immanent compared with the South-Slav concreteness and 
directness. Tense episodes about everyday dramas of Turkish characters make a contribution for better understanding of cultures and people individually and they also break stereotypes in a subtle and positive manner.

\begin{abstract}
What really hooks viewers are the rollicking storylines. The secret of a good soap is that all human joys and troubles are there, usually larger than life. The Grapevine Mansion (Asmall Konak), the first great Turkish soap, debuted back in 2002. It was the tale of an urban sophisticate who marries into a small-town family living in an old mansion. There, she comes face to face with the old Turkey that most viewers left behind just a generation ago: blood feuds, illegitimate children, the bitter rivalries of the women of the house. Noor, turning the same theme on its head, is a Cinderella tale of a village girl who marries a rich Istanbul hunk, overcomes the envy of his evil mother and sister, and (spoiler alert) eventually saves the family textile business. Last year's crop of Turkish soaps were edgier: 1001 Nights (Binbir Gece) follows a widow forced to sleep with her boss to get medicine for her son's leukemia; Forbidden Love (Aşk-ı Meтnu) (is a roller coaster of suicide, betrayal, and adultery featuring an immoral mother and a vengeancedriven daughter (Matthews, 2012).
\end{abstract}

\title{
Postmodern Genre Transgression
}

Series which follow the genre of melodrama, and base their story on conflicts and intrigue plots, got a popular name Soap opera as the first commercials for the cleaning products were advertized during the series. These series were firstly created for radio programs in the 1930s of the last century and the culmination was seen on television in the form of American series. Their expansion started in the 1940s. Commercials for cleaners were firstly interpolated in the series because they were originally designed for housewives. Derogatory connotations of the term are 
determined by the irony of the word opera, because in these series everyday life is raised to the level of tragedy and pathos of opera. Talking about television genres, there is a clear difference between drama (drama series) and soap opera. This latter one is a product of a happy marriage between the commercial features of media industry and dramatic narration in series. A new episode is possible thanks to an open end which attracts the viewers to watch the next episode. Originally oriented to internal family dramas of rich people in 1960s, through the series Days of Our Lives, the plots with a doctor as the main character were introduced. This innovation will have its genealogy in today series that deal exclusively with medical environments. However, the soap opera will wait for another twenty years to get its hybrid genre. This happens when the vast interior space with the houses of rich people, as a connotation of power, are replaced with smaller interiors (and with them come the characters from the middle class) in which the plot other than that of family one is built outside of the home that is in the workplace.

Bestselling author and a student of medicine, Michael Crichton, in 1974 gives the idea for a soap that takes place in a hospital. Steven Spielberg's involvement in the development of the show resulted latter in the worldwide popular series: ER. In the 1990s the series are more technologically and visually advanced and more drama and comedy oriented. The new sitcom genre emerges, as well as detective story based serials. Nevertheless, the soap opera is primary based on human interrelations and intrigues. 
However, it is important to emphasize that although the soap opera can have supernatural elements, like the gothic soap opera Dark Shadow from 1960s, where the main character is a vampire, an essential defference between the series such as True Blood of today and the former soap operas exist not only in regard to the technological quality of production (soap opera characteristics: three point lighting, scenes ending with dramatical pause and close-ups, interior grandure, lower visual quality then that of the feature movies and TV mini series), but also in the narrative structure. For example, a diference between soap opera and telenovela is in the structure of the narration, but also in the features of TV industry. Both have developed as melodramatic stories, from the very begining of radio broadcasting, with an aim to unite cultural space and integrate Latin continent and create national hegemony, but only in 1980-ies the Latino-American telenovelas has become known all over the world. Essential genre characteristics between telenovelas and soap operas are as folows:

- telenovela has a limited duration (usually it is 7 months) while the soap opera is with no limits with regard to duration;

- telenovela is a product developed for the prime-time and the soap opera is not necessarily a prime-time product;

- the basic plot of telenovela show is love;

- telenovela clings firmly to the structure of melodrama with a hapy ending;

- evil, obstacles, intrigue, deceit, infidelity are the obstacles that will ultimately guarantee success for the telenovela protagonists (there is a very strong religious and cultural imperative - Way of the Cross), 
while in the soap opera these drama tools are invented for entertainment;

- telenovela main characters belong to middle class, nationalism is propagated as well as the differences between the classes where the rich are to be blamed for, but in the soap operas the main issue is an intrigue between the rich;

- telenovela outlines differences and promotes teamwork, while the soap opera tends unification and globalization, through individualism.

Therefore, ,soap operas are of two basic narrative types: 'open' soap operas, in which there is no end point toward which the action of the narrative moves; and 'closed' soap operas, in which, no matter how attenuated the process, the narrative eventually close“ (Allen, unknown). In classification of genres that derived from soap operas it would be more accurate to name the letter one as telenovelas. However, only this differentiation is not sufficient for the classification within this television genre. Today, even those serials with five or more seasons, which might correspond to a soap-opera melodramatic narrative structure, are not named ,derogatory“ but are labeled with thematic feature and given the hybrid genre label: teen drama, vampire series, historical drama, action series, police series, detective, forensic, etc... Soap opera been a boast for generating a number of mixed genres that appear after the exhaustion of certain themes in classical genres. The genre here is not determined only by the self-defining elements of the narrative, but with the regulations of television distributions and broadcasting contracts with productions and advertizing agencies. It is essential not to 158

Epiphany: Journal of Transdisciplinary Studies, Vol. 7. No. 1, (2014) @ Faculty of Arts and Social Sciences 
overlook the narrative components of Turkish series. Are they really fitting into a soap opera narrative models?

Turkish series in Bosnia and Herzegovina are broadcast every day in different parts of a day, and they usually cover prime-time. But in Turkey the same series are broadcast differently: once in a week where an episode lasts at least 90 minutes and it resembles dramaturgically and with the form of directing to a feature film. Therefore, along with the already mentioned genre characteristics, it is necessary to analyze the structure of the plot and development of characters in order to determine genre classification.

The main characteristics of telenovela are as follows: the basic plot and conflict is love; the action has a melodramatic discourse; Hero, Villain and Heroine dramaturgy; a happy ending - wedding (Panjeta, et. al, 2005, \& Mazziotti, 1996). Characters' development and plots in telenovelas are comparative to the biblical allegories of the Cross Way, Passion of the Christ, and the Heavenly Kingdom. The reward in Heaven awaits those who suffer in this life. Such religious dualistic concept of justice and life suffering is not inherent in the Islamic world. However, this Christian philosophy is the main narrative discourse for the melodrama and telenovela.

Genre characteristics of Turkish series do not require necessarily a happy ending. Sometimes it is completely contrary to this. Series end tragically, although the melodramatic narrative structure suggested happy ending. The best indicator for this claim is the tragic end of the leading male character Halil, who is killed by his 
opponent at the very end of the love plot based series Menekşe ile Halil. Along with the fact that the characters and plots overcome the usual clichés there are also many variations regarding the aforementioned characteristics of soap operas and telenovelas. Therefore, Turkish series cannot be considered telenovelas because here the very genre goes through the modeling process and some of the main rules of telenovela genre are broken.

Altman designates the "genre as process" (54-42) and explains that mixed features of classical genres come from rebellion against Classicism that was the characteristic of Romanticism as a movement and literature genre. "What we perceive as a mixture of pre-existing genres is often nothing less than the liquid lava of new genre still in the creation process" (Altman, 1999, p. 143). Mixed genre is also a consequence of the postmodern thought. It might be true to call the postmodern transgression of the soap opera genre to new mixed genres of drama serials, for which a good example is the Turkish serials. Although, we haven't gotten a new genre here, but the hybrid genre which mixes the TV series narrative structure and TV broadcasting rules with that of the classical narratives.

Some of the Turkish series are based on the classical works of literature or critically acclaimed novels. The examples of these adaptations are as follows:

- Yaprak Dökümü is besed on the novel by Reşat Nuri Güntekin written in 1939;

- Fatmagül'ün suçu ne? is an adaptation of the Vedat Turkali novel and the film with the same title made in 1986;

- Kesanli Ali Destani is filmed version of the most famous Turkish musicle with the same name from 1964; 
- The scenario for the Hanımın Çiftliği is based on the novel Hanımın Çiftliği written by Orhana Kemal (Mehmet Raşit Öğütçü);

- Dudaktan Kable is an adaptation of the famos novel written by Reşat Nuri Güntekin with the same title published in 1923;

- Ezel is inspired by the popular novel Grof Monte Cristo written by the French writter Alexandre Dumas;

- Leyla ile Mecnun is an adaptation of a famos Arab love story;

- Şubat is based on the classical fairy-tale The Beauty and the Beast.

Given that the genre elements, which determine the categorization of soap operas and telenovelas, are narrative and industry related differentiating ones, in case of Turkish series it is necessary to make an insight not only into the narration, which uses classic patterns for screenplays, but also in directing and development of characters. The use of film language is different in the Turkish series than in telenovelas:

- moving camera, often dolly and tracking shots

- blocking the dialogs in non stationary and non conservative screen direction

- close-ups are in the function of the action, and not the tension elevating tool

- slow motion, overlapping and other editing filmmaking techinques are following the basic storyline by building the suspense and surpise, they are completly justified

- soundtrack following the action in a movie like manner

- deus ex machina dramaturgy solutions and evil characters per se are not so common

- script development of the character and acting is more sofisticated

- stories are life based, and dramatic creative solutions real, becouse the characters are not dualisticly antagonized betweed good and evil, but rather consequences of the character's decisions are the spin wheel for the plot.

Determining factor that separates the Turkish series out of telenovelas is the vitality of their stories and the manner of technical realization. Characters are not set or preset, but evolving, just as in the works of classical literature. Almost 
Tolstoy characters and Shakespeare plotlines are placed into the context of everyday life, but not in an artificial manner of dues ex machina plots. Specifically, in the Turkish series, compared to soap operas or telenovelas, there is an organic compound of everyday life and tragedy elements. In the series Fatmagül'ün suçu ne?, there is a statement that Fatmagül (a raped girl) has a strong heart to which she answers: „I must have it to survive“. Here the moving force is not an already given character, but she is the character who transforms from gentle girl into a strong woman, but not because it is necessary for the story to develop from it, but because it has to be so in order to continue with life from which the narrative here happens. There is no room for pathos for its own sake, but the action is moved by the rigors of survival. „There is nothing with which stories are intimately concerned, then the conflict between 'dark' and 'light'، (Booker, 2004, p. 700). Negative characters in the Turkish series are not entirely negative in themselves. They are more like the ancient heroes who, for reasons of pride or arrogance (hybris) are caught in the web of their own actions that end tragically. A good example is the replica of a villain from the aforementioned series, Reşat Yaşaran: „We live and experience everything. If your child commits a crime, would you let him to the fate to decide. I cannot." Within the basic clichés of good and evil narrative, the Turkish series offer us the new-old patterns of classic dramaturgy. 


\section{Concluding Remarks}

According to Lešić (2005) "human's confrontation with circumstances that are not controlled by his/her own will but by God's will, or the very Fate (in Greek Moira) as the force even stronger than the one of Gods, which is why any disobedience of a human, his/her violation of given human limits or arrogance, his/her hybris, becomes a 'tragic guilt' of his/hers, and he/she becomes victim sentenced to suffering and anguish" (p. 487). This is how the understanding of the Heroes Flaw in Greek tragedies is described. In Turkish series we do not expect the wedding of the main character or unmasking of the villains as we would in telenovelas melodramatic stories. Not looking forward to see demise of the characters, just as the protagonists (the so-called positive figures) do, but as in a classical tragedy, in the process of catharsis, we are feel pity for the complete situation in which not willingly, but as a result of certain own decisions and fate's (hybris and Moira) the characters found themselves.

Defining the hero in tragedies, Aristotle (2002, p. 77) described him as the one ,who is not eminently good and just, yet whose misfortune is brought about not by vice or depravity, but by some error or frailty." The development of the character in Turkish series is made according to this definition. However, these are not ancient Greek heroes, but everyday life people are forced to walk the path of the hero in order to survive in the world that is almost mythically cruel. The narrative taken as mythos (a story deriving from a meaning for a particular culture), and the 
development of the character taken as everyday life hero, are the differentiating elements of this genre, which cannot be called telenovelas. "Myths are stories that people have recounted to explain themselves to themselves and to the others. But Aristotle developed this insight in philosophical outlook when ... argued that the art of storytelling is the one ... we owe the experience to share this world with others" (Kearney, 2009, p. 13). It is through the Turkish drama series, where reality, character evolve, and livingness are inherent as well as the sharing of intimate experience of the world with others, that this global voyeuristic demand for narratives found its embodiment.

The tragic concept in contemporary drama was already finished with Hegel's consideration of individuality, which is therefore not a mirror of the higher fatal forces, but a particular case. Universality of our pastime today is not comparable with the mythic universality, but the elements of the tragic vision of the world in the highly profitable and popular products, which the Turkish series surely are, actually do exist. Globalization, social impact and cult that the popularity of series carries with them, and the narrative models found in Turkish series raises them to a new higher level, which differs from the genre within which they originally were created. From probably the first serial storytelling, like for example Schereherazade's stories in a classic work One thousend and One Nights, a visualization techniques, as the cinematic storytelling, have evolved. The genres developed, characters are individualized, cultures damasked and stereotypes 
smashed, identification of audience and development of virtual cults was intensified, and via Turkish series the classic narrative forms found their fans among the mass audience.

\section{Index of TV Series and Films}

Aksan, B. (Writer) \& Ünlü, O. \& Boz, E. (Directors). (2011-2013). In O. Ünlü \& F. Alp (Producers) Leyla ile Mecnun. EFLATUN FILM.

Alp, F. \& Ünlü, O. (Writers) \& Kocatürk, V. (Director). (2012-2013). In F. Alp \& O. Ünlü (Producers) Şabat. EFLATUN FILM.

Ball, A. \& Harris, C. et al. (Writers) \& Lehman, M. Winant, S. et al. (Directors). (2008-2013). In A. Ball (Executive Producer), True Blood. HBO

Canpolat, E. \& Ergenekon, S. (Writers) \& Alpagut, T. \& Uzun, K. (Directors). (2005-2007). In I. Şahin (Producer), Gümüş. ANS PRODUCTIONS.

Curtis, D. Wallace, A. Russell, G. Hall, S. et al. (Writers) \& Swift, L. Kaplan, H. Sedwick, J. Sullivan S.D. et al. (Directors) (1966-1971). In D. Curtis \& R. Costello (Producers), Dark Shadows. DAN CURTIS PRODUCTIONS.

Deren, K. \& Bulut, P. (Writers) \& Bayraktar, U. (Director). (2009-2011). In K.Çatay (Producer), Ezel. AY YAPIM.

Ergun, M. (Writer) \& Irmak, Ç. (Director). (2002-2004). In A. Oguz (Producer), Asmalı Konak. ANS PRODUCTIONS.

Lumiere, A. \& L. (Directors). (1895). In Lumiere, A. \& L. (Producers) L'arrivée d'un train en gare de La Ciotat.

Okay, M. \& Şahin, Y. (Writers), \& Taylan, Y. \& Taylan, D. (Directors). (20112013). In T. Savci (Producer), Muhteşem Yüzyil. TIMS Productions.

Tunç, Y. \& Dede, M.B. \& Lüftü, M. and Yekta, E. (Writers) \& Sabanci, K. (Director). (2006-2009). In E. Avci (Producer), Binbir Gece.TMC.

Yörenç, E. \& Gençoğlu, M. (Writers) \& Bayraktar, U. (Director). (2007-2008). In K. Çatay (Producer), Menekşe ile Halil. AY YAPIM.

Yörenç, E. \& Gençoğlu, M. (Writers) \& Erarslan, M (Director). (2005-2010). In K.Çatay (Producer), Yaprak Dökümü. AY YAPIM. 
L. Panjeta The Changing Soaps and Telenovela Genre: Turkish Series Impact

Yörenç, E. \& Gençoğlu, M. (Writers) \& Haznedaroğlu, A. (Director). (20072009). In K.Çatay (Producer), Dudaktan Kalbe. AY YAPIM.

Yörenç, E. \& Gençoğlu, M. (Writers) \& Saral, H. \&Yöş. B. (Directors). (20082010). In K.Çatay (Producer), Aşk-ı Memnu. AY YAPIM.

Yörenç, E. \& Gençoğlu, M. (Writers), \& Saral, H. (Director). (2010-2012). In K.Çatay (Producer), Fatmagül'ün suçu ne?. AY YAPIM.

Yücel, Z. (Writer), \& Teber, F. (Director). (2009-2011). In F. Turgut (Producer), Hanımın Çiftliği. GOLD FILM.

Yula, Ö. (Writer) \& Irmak, Ç. (Director). (2011-2012). In E. Sakarya (Producer) Kaşanli Ali Destani. D Construction.

Yurdakul, A. \& Şaşmaz, R. \& Özderen, B. (Writers) \& Sinav, O. (Director). (2003-2005). In R. Şaşmaz (Producer), Kurtlar Vadisi. PANA FILM.

\section{References}

Allen, R. (unknown) Soap Opera. MBC The Museum of Broadcast Communication. Retrieved from

http://www.museum.tv/eotvsection.php?entrycode=soapopera

Al Tamimi, J. (2012, April 2). Challenge of the Turkish Soap Operas. Gulf News. Retrieved from

http://gulfnews.com/business/features/challenge-of-the-turkish-soapoperas-1.1002249

Altman, R. (1999). Film/Genre London: British Film Institute, Palgrave Macmillan.

Anonymous (2012, July 16). Famous TV series to air earthquake scenes to raise awareness. Hurriyet Daily News. Retrieved from http://www.hurriyetdailynews.com/TurkRadio.aspx?pageID=238\&nI $\mathrm{D}=25594$

Anonymous, (2012, November 25). Turkey's PM Erdoğan slams TV series about Ottoman sultan. Todayszaman.com. Retrieved from http://www.todayszaman.com/news-299316-turkeys-pm-erdoganslams-tv-series-about-ottoman-sultan.html

Aristotel. (2002). Poetika : O pjesničkoj umjetnosti. Beograd: Dereta. Transl. Đurić, N. (Original work approximately 350 BC) 
L. Panjeta The Changing Soaps and Telenovela Genre: Turkish Series Impact

Booker, C. (2004). The Seven Basic Plots : Why We Tell Stories. London, New York: Continuum.

Canikligil, R. (2012, March 7). Mary’ye 'Kerim' terapisi. Hurriyet. Retrieved form

http://www.hurriyet.com.tr/planet/20070921.asp

Dervišević, F. (2012, Septembar 7). Turska TV industrija - turske serije. Retrieved from http://tvnovele.motion-forum.net/t11589-turska-tvindustrija-turske-serije

Dežulović, B. (2012, August 30). Suljo Veličanstveni. Oslobodjenje, p. 11

Fiddy, D. The Cult of Cult TV?. in Abbott, S. (Ed.). (2010). The Cult TV Book. London, New York: I.B. Tauris \& Co Ltd.

Hirshfeld, R. (2012, December 7). Turkish Soap Opera Inspires Murder, Clerics Blame 'West'. Israelnationalnews. Retrieved from http://www.israelnationalnews.com/News/News.aspx/157781\#.UTPCr $\underline{6 \mathrm{I} 3 \mathrm{uSo}}$

Ilić, N. (2012, March 7). Istorijski falsifikat: "Romantični Sulejman nabijao srpske glave na kočeve!. Telegraf. Retrieved from http://www.telegraf.rs/vesti/104524-istorijski-falsifikat-romanticnisulejman-nabijao-srpske-glave-na-koceve

Jasmina, M. (2012, August 30). Turska TV industrija - turske serije. Retrieved from

http://www.forum.hr/showthread.php?t=738745

Kasapović, M. (2012, September 8) Sulejman Veličanstveni ponovno pokorio Balkan. Večernji list. Retrieved from http://www.vecernji.hr/vijesti/sulejman-velicanstveni-ponovnopokorio-balkan-clanak-450882

Kearney, R. (2009). O Pričama. Zagreb: Naklada Jesenski i Turk.

Kimmelman, M (2010, June 17). Turks Put Twist in Racy Soaps. NYTimes. Retrieved from

http://www.nytimes.com/2010/06/18/arts/18abroad.html?_r=0

Kirbak, Y. (2012, August 5). Greek neo-Nazi party calls for boycott to Turkish soap operas. iHurriyet.com.tr. Retrieved from http://www.hurriyetdailynews.com/greek-neo-nazi-party-calls-forboycott-to-turkish-soap-operas-.aspx?pageID $=238 \&$ nid $=27098$ 
Krajeski, J. (2012, March, 30). Turkey: Days of Their Lives. Pulitzercenter. Retrieved from

http://pulitzercenter.org/reporting/turkey-diyarbakir-kurdish-rolessoap-opera-politics-ayrilik-olmasaydi

Lešić, Z. (2005). Teorija književnosti. Sarajevo: Sarajevo Publishing.

Matthewes, O. (2011, September 5). The Arab World's 'Dallas'. In Newsweek Magazine. Retrieved from

http://www.thedailybeast.com/newsweek/2011/09/04/turkish-soapoperas-are-sweeping-the-middle-east.html

Mazziotti, N. (1996). La industria de la telenovela. Buenos Aires: Editorial Paidos.

Nahmias, R. (2012, June 4). Palestinian women outraged over Turkish TV series. Israel News. Retrieved from http://www.ynetnews.com/articles/0,7340,L-3872384,00.html

Panjeta, L., Mazziotti, N., Spahić, B., \& Sanchez, L. (2005). Telenovela fabrika ljubavi, Uvod u produkciju $i$ žanr (Telenovela - La fabrica del amor, Introduccion al genero y a la produccion). Sarajevo Naklada Zoro \& HEFT.

Rohde, D. (2012, March 9). The Islamic World's Culture War, Played Out on TV Soap Operas. Reuters. The Atlantic. Retrieved from http://www.theatlantic.com/international/archive/2012/03/the-islamicworlds-culture-war-played-out-on-tv-soap-operas/254247/

Staff. (2012, April 4). Tukish soap opera blamed for UAE divorces. Emirates.news. Retrived from

http://www.emirates247.com/news/emirates/turkish-soap-operablamed-for-uae-divorces-2012-04-04-1.452235 